Article

\title{
Bio Briket Cangkang Aleurites Moluccana Melalui Gelombang Elektromagnetik Dengan Varian Daya Dan Durasi Waktu Karbonisasi
}

\author{
Rini Kartika Dewi ${ }^{1}$, M. Istnaeny Hudha ${ }^{1}$, Ferry Darmawan S.S. ${ }^{1}$, Dendy Wono Prasetyo ${ }^{1}$ \\ ${ }^{1}$ Institut Teknologi Nasional Malang dan Jl. Bendungan Sigura-gura no. 2 Malang \\ E-mail: rinikd@yahoo.co.id, istnaeny.hudha@gmail.com (*Corresponding author)
}

\begin{abstract}
Bio briquette is a source of energy derived from biomass and can be used as a solid fuel instead of petroleum and other energy derived from fossils. Bio briquettes are one of the alternative solutions that are quite effective and efficient in dealing with the crisis of energy sources, one of which is by optimizing the pecan shell or shell of Aleurites moluccana as a bio briquette. Pecan shell is a waste that is very abundant in Indonesia and can be used as a solid fuel that is environmentally friendly and has a high calorific value. The purpose of this study was to determine the influence of microwave electromagnetic waves on the bio briquette quality of pecan shells through power variants and the duration of carbonization time. The stages are pecan shell cleaning, carbonization process with microwave electromagnetic waves at predetermined power and duration of time (0.5, 1, 1.5 and, 2 hours), the process of crushing into charcoal with disk mill equipment, mixing with adhesive material with a ratio between the mass of charcoal and adhesive material 80:20 (b/b), bio briquette printing and the last stage is drying with sunlight for 2 days. From the analysis obtained the most optimum results are at 440 watts of power for 1 hour with the following results: water content of $7.30 \%$, ash content: $7.48 \%$, Carbon Bound obtained: $73.31 \%$, Volatile matter: $30.23 \%$ and, the calorific value of bio briquette is: $5706.24816 \mathrm{cal} / \mathrm{gram}$
\end{abstract}

Keywords: bio briquette, pecan shell, electromagnetic wave, carbonization, microwave

EQUILIBRIUM Volume 4 No.2 December 2020

Online at http://equilibrium.ft.uns.ac.id 


\section{Pendahuluan}

Penggunaan energi di Indonesia sebagian besar berasal dari energi yang berasal dari bahan bakar fosil seperti minyak bumi dan gas alam, dimana penggunaan fosil semakin meningkat seiring dengan bertambahnya populasi manusia. Sumber bahan tersebut merupakan bahan yang tidak dapat diperbaharui. Hal ini menjadikan kekhawatiran akan terjadinya krisis bahan bakar, sehingga harus segera mencari solusi atau upaya untuk mengatasi masalah tersebut. Salah satunya dengan mencari dan mendapatkan sumber energi alternatif yang memiliki cadangan alam yang berlimpah dan mudah. Beberapa jenis sumber energi alternatif yang bisa dikembangkan antara lain adalah energi matahari, energi angin, energi panas bumi dan energi biomassa. Diantara sumber-sumber energi alternatif tersebut, energi biomassa merupakan energi alternatif yang sering digunakan dalam pengembangan energi alternatif. Energi biomassa merupakan energi yang diperoleh dari limbah hasil perkebunan, pertanian dan hutan. Tanaman kemiri (Aleurites mollucana L, Willd) merupakan jenis tanaman yang mudah ditanam, cepat tumbuh dan tidak begitu banyak menuntut persyaratan tempat tumbuh, ${ }^{1}$ dan limbah yang dihasilkan dari proses pemecahan biji kemiri berupa tempurung kemiri selama ini belum dimanfaatkan secara optimal, padahal apabila diolah kembali akan menjadi lebih bermanfaat seperti untuk produk arang aktif. ${ }^{2}$

Bio Briket adalah suatu bahan bakar padat yang dibentuk dari hasil pencampuran limbah organik dengan perekat dan zat-zat lain sehingga mampu berguna dalam pembakaran. Bio Briket yang baik harus memenuhi standar yang telah ditentukan agar dapat digunakan sesuai dengan keperluannya yaitu antara lain mencakup nilai kadar air, porositas dan nilai kalor, zat yang mudah mengaup, total karbon dll. Penelitian yang sudah memanfaatkan limbah biomassa dari pertanian sebagai briket seperti ampas tebu, kulit ubi kayu, cangkang kelapa, sekam, jerami dan kulit durian sudah cukup banyak. Hasil penelitian mereka menunjukkan bahwa briket yang dihasilkan sesuai standar SNI yaitu memiliki kadar air range antara 3-8\%, kadar abu range antara 5,37-15\% dan memiliki nilai kalor bersikar $5000 \mathrm{kkal} / \mathrm{g} .{ }^{3}$ Pada proses pembuatan briket umumnya memerlukan perekat dan memiliki peran yang cukup besar. Berdasarkan penelitian terdahulu menunjukkan semakin besar persentasi bahan perekat, maka semakin tinggi pula kadar air dan kadar abunya, sehingga nilai kalornya menurun. 4,5,6. Sedangikan penelitina lain mengatakan bahwa tepung tapioka merupakan salah satu jenis perekat terbaik dibandingkan dengan molasses dan silikat. Hal ini dapat dilihat dari nilai kalor yang lebih tinggi dibandingkan dengan yang lainnya yaitu sebesar $6748,69 \mathrm{kal} / \mathrm{gr}^{7}{ }^{7}$ Penelitian tentang pembuatan briket arang dari campuran buah bintaro dan tempurung kelapa menggunakan perekat amilum. Buah bintaro dan tempurung kelapa dapat ditingkatkan nilai ekonomisnya dengan cara memanfaatkannya sebagai bahan baku pembuatan briket arang dan briket arang yang dihasilkan dari bahan baku buah bintaro dan tempurung kelapa dapat dijadikan alternatif bahan bakar karena kualitas briket yang dihasilkan sesuai dengan standart yang ada. ${ }^{8}$ Berdasarkan kajian dari penelitian sebelumnya dan melihat adanya potensi kulit buah bintaro, dalam penelitian ini kulit buah bintaro akan dimanfaatkan sebagai bahan utama pembuatan briket arang.

Dalam proses pembuatan bio briket selain bahan perekat maka proses karbonisasi atau pengarangan sangat berpengaruh terhadap produk bio briket yang dihasilkan. Untuk proses katbonisasi dapat digunakan secara pirolisis ataupun tungku pembakaran, furnace. Selain alat tersebut dapat juga menggunakan peralatn microwave seperti penlitin terdahulu yang menggunakan microwave untuk delignifikasi pada cangkang kemiri menggunakan kombinasi microwave dan larutan $\mathrm{NaOH} .{ }^{9}$

Kebaharuan dari penelitian ini adalah peneliti menggunakan gelombang elektromagnetik microwave untuk proses karbonisasinya dengan variasi daya. Diperkirakan semakin tinggi daya yang digunakan maka akan semakin besar gelombang mikro yang dihasilkan dan semakin tinggi pula suhu yang dihasilkan oleh microwave. Oven microwave mengubah energi listrik menjadi energi panas sehingga alat ini bisa bekerja memanaskan makanan di dalamnya. Sesuai dengan persamaan rumus energi:

$$
P=E / t
$$

Daya berbanding lurus dengan jumlah energi yang dihasilkan tiap satuan waktu. Semakin besar daya yang digunakan maka akan semakin tinggi energi yang dihasilkan. Selain itu kebaharuan yang lain adalah dalam penggunaan bahan perekat. Untuk bahan perekat yang kami pergunakan adalah tepung Ganyong yang mana kebanyakan peneliti terdahulu menggunakan tepung tapioka. 


\section{Metode Penelitian}

Bahan baku yang digunakan adalah cangkang kemiri dan perekat yang digunakan antara lain tepung ganyong. Peralatan yang digunakan antara lain microwave, disk mill untuk menghancurkan,timbangan analitik, desikator, alat pengepres.

Prosedur penelitiannya adalah sebagai berikut :

Proses Awal Pembuatan Tepung Ganyong

Ganyong dan dipotong kecil-kecil dan dibersihkan dengan air. Kemudian direndam dengan $\mathrm{NaCl}$ selama 1520 menit kemudian direndam untuk menghilangkan lender atau getah dengan Natrium metabisulfit untuk menghilangkan bau dan sisa-sisa lender yang masih ada selama 15-20 menit yang ada dalam ganyong dan gembili. Setelah itu dibilas dengan air, ditiriskan dan dikeringkan dengan bantuan sinar matahari atau dimasukkan ke dalam oven pada suhu $110^{\circ} \mathrm{C}$ selama 1 jam. Dihancrkan ke dengan alat disk mill hingga berbentuk tepung (Gambar 1).

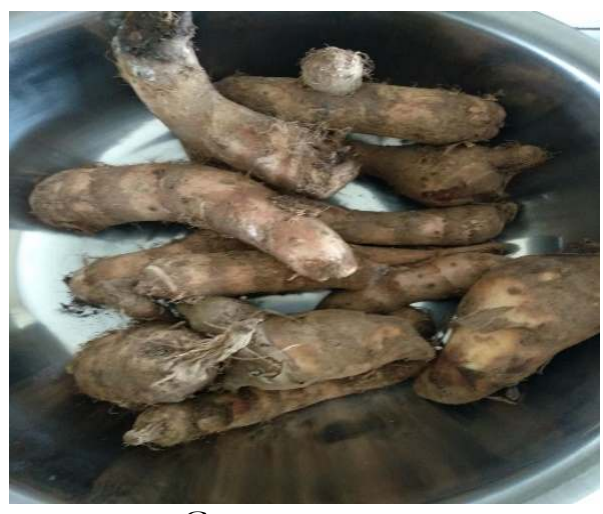

Ganyong

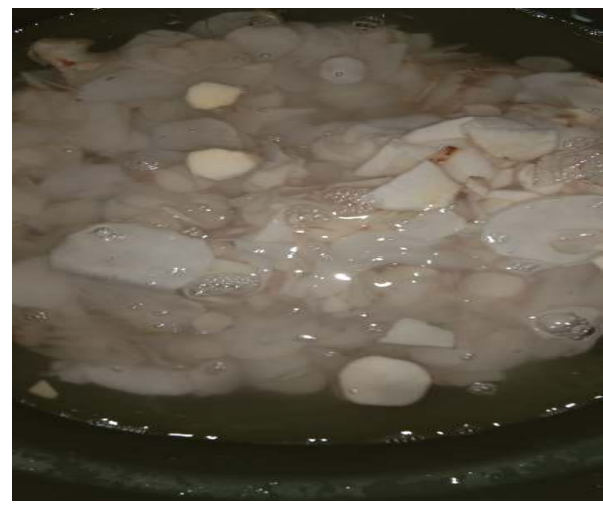

Perendaman $\mathrm{NaCl}$

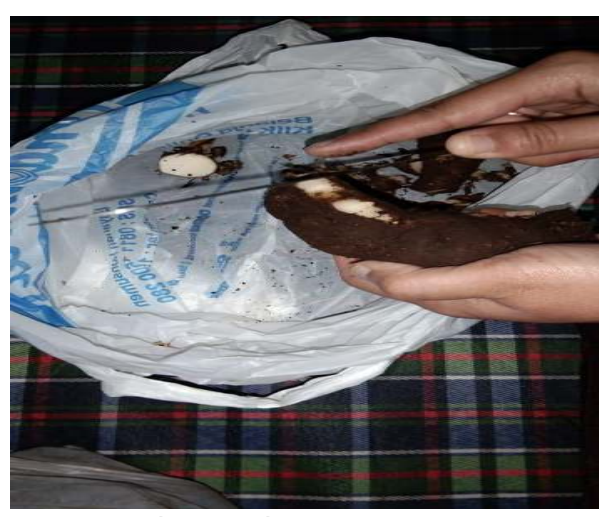

Proses Pengupasan

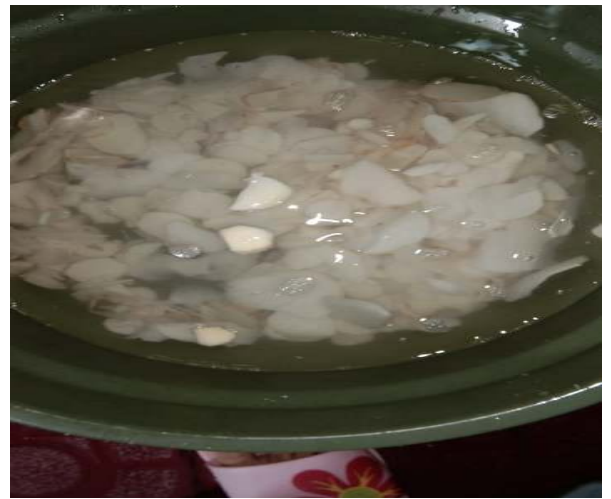

Perendaman Natrium Metabisulfit

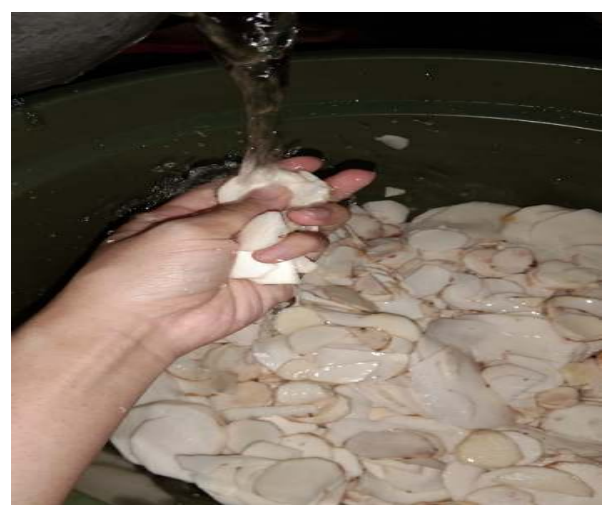

Pembilasan dengan Air

Bio Briket Cangkang Aleurites Moluccana Melalui Gelombang Elektromagnetik Dengan 


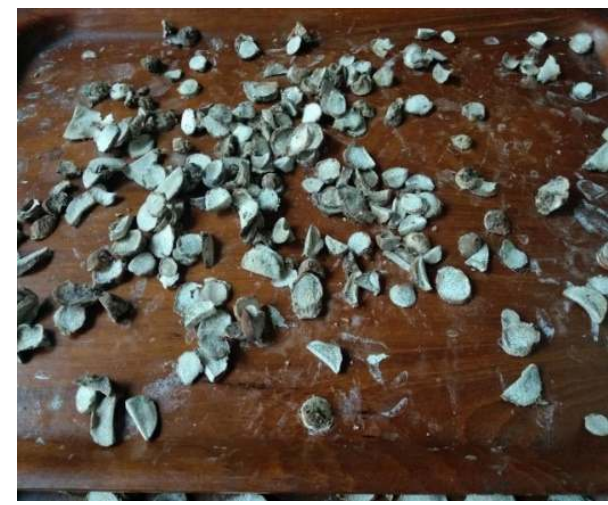

Pengeringan Dengan Sinar Matahari

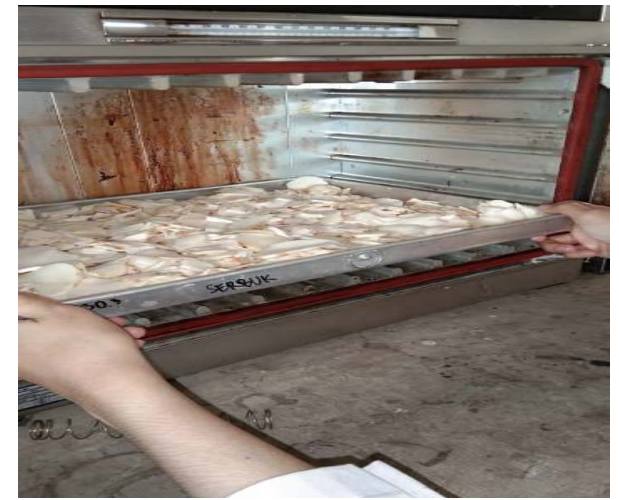

Pengeringan dengan Oven
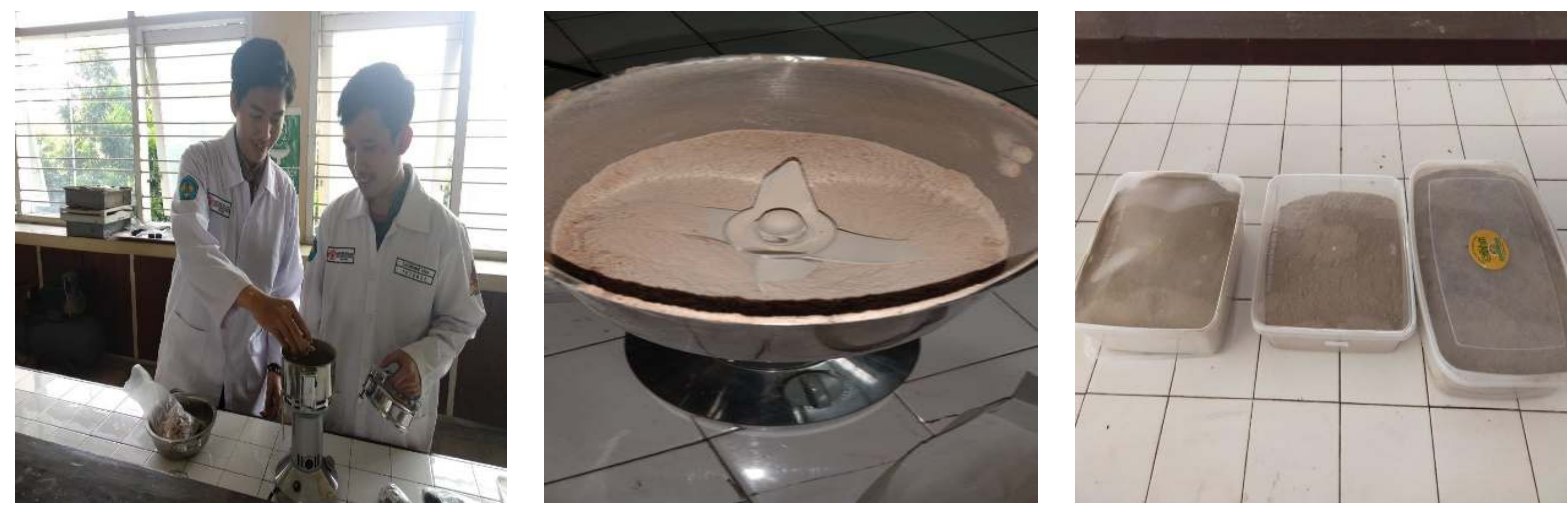

Penghancuran dengan Disk Mill Sampai Menjadi Tepung

Gambar 1. Proses Pembuatan Tepung Ganyong

Proses Persiapan Cangkang Kemiri Untuk Biobriket

Pada tahap awal, cangkang kemiri dilakukan pensortiran, dibersihkan terlebih dahulu dari impuritis yang terikut.

\section{Proses Karbonisasi}

Cangkang kemiri yang sudah dibersihkan dimasukkan kedalam microwave dengan variasi daya dan durasi waktu (0.5, 1, 1.5 dan 2 jam). Dari Microwave cangkang kemiri dikeluarkan dan dibiarkan selama 10 menit sehingga suhunya turun. Kemudian dihancurkan dengan disk mill sehingga didapatkan arang cangkang kemiri (Gambar 2).
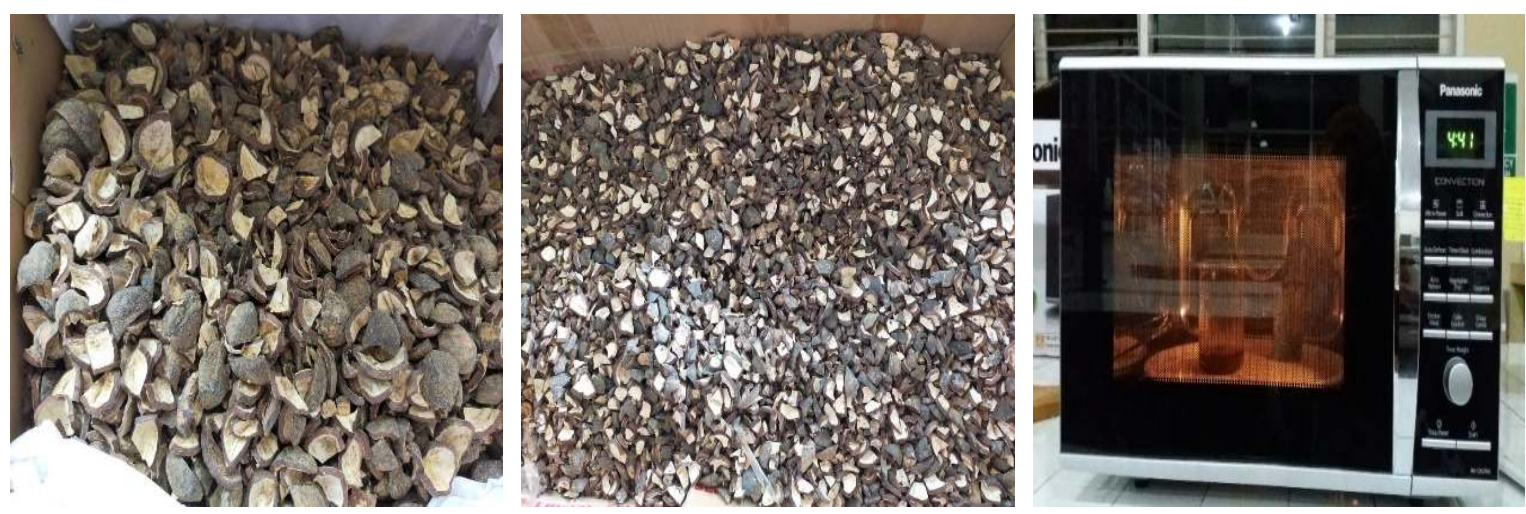

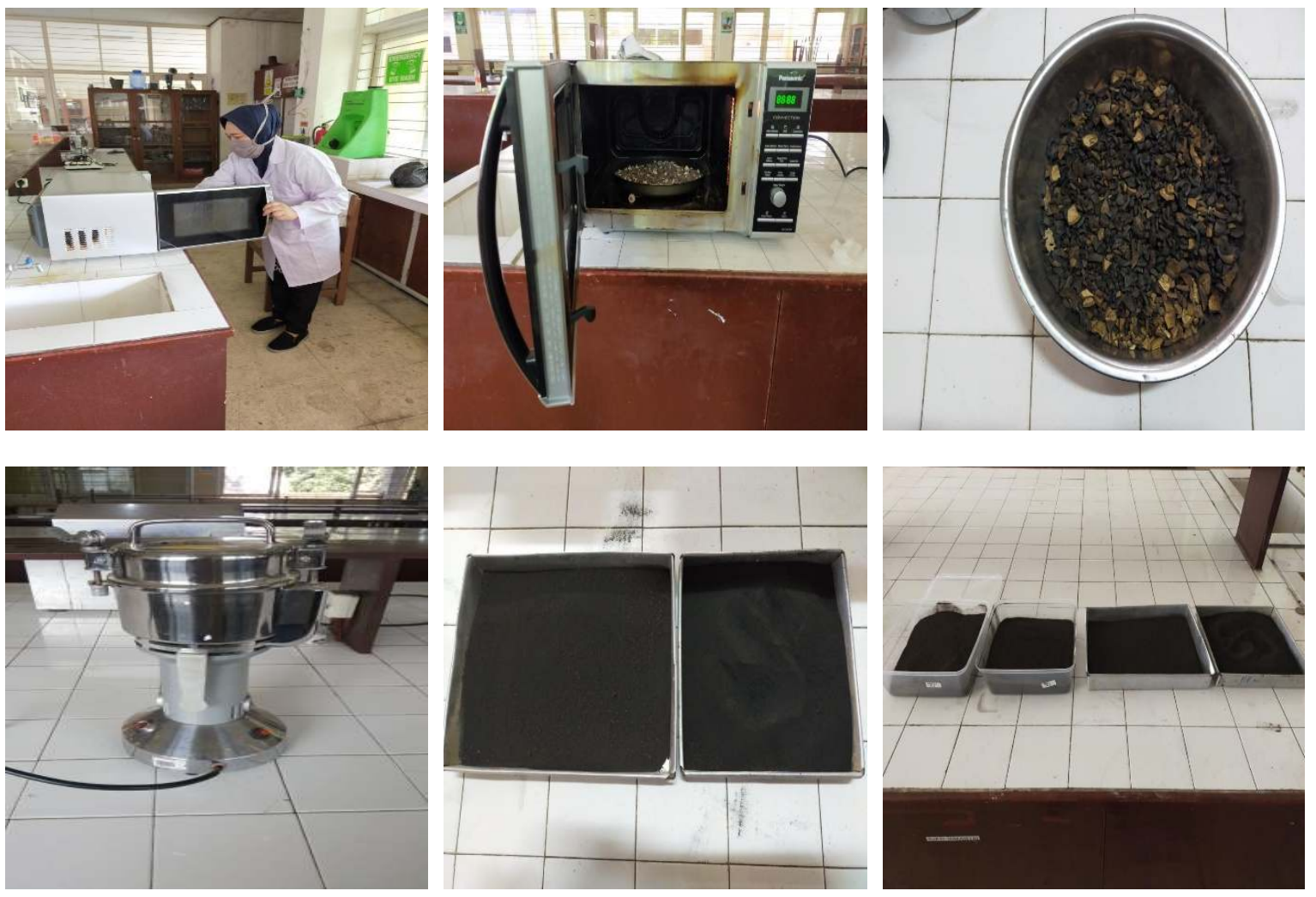

Gambar 2. Proses Karbonisasi

\section{Proses Pembriketan}

Arang tempurung atau cangkang kemiri yang telah didapatkan ditambahkan dengan perekat dari perekat tepung ganyong dengan rasio perbandingan antara arang cangkang kemiri dan perekat (80:20) b/b, kemudian ditambahkan dengan $250 \mathrm{ml}$ air panas diaduk hingga rata sampai adonan siap untuk dilakukan pencetakan.

\section{Pencetakan dan pengempaan}

Pencetakan adonan briket dilakukan saat adonan briket sudah homogen atau tercampur dengan sempurna. Adonan briket dimasukkan kedalam alat pencetakan., kemudian dikempa

dengan alat pengepres briket hidraulik yang dilengkapi dengan pemanas dengan tekanan yang besar hingga padat. Biobriket yang dihasilkan adalah berbentuk silinder dengan ukuran diameter $3 \mathrm{~cm}$ dan tinggi $4 \mathrm{~cm}$.

\section{Pengeringan}

Pengeringan dilakukan dengan cara dijemur di bawah sinar matahari langsung selama 2 hari. Hal ini bertujuan agar didapatkan kadar air sesuai SNI yaitu 8\%. Selanjutnya biobriket dari tempurung atau cangkang kemiri dikemas dan dilakukan analisa proximate yang meliputi kadar air, kadar abu, Fix Carbon, Volatile matter, serta analisa kalori pembakaran dengan menggunakan bomb kalorimeter.

\section{Hasil dan Pembahasan}

Bio briket cngkang kemiri dan jenis perekat dari tepung ganyong dengan perbandingan komposisi arang dan perekat : $80: 20(\mathrm{~b} / \mathrm{b})$. Hasil penelitian terhadap kualitas dari bio briket yang dihasilkan dapat dilihat pada Tabel 1.

Dari Tabel 1 dan 2 diketahui bahwa pada kadar air dengan ke empat variasi masih memenuhi SNI yaitu $\leq 8$, kadar abu pada ke empat variasi hanya dengan daya 250 watt yang memenuhi SNI dengan nilai $\leq 8$, sedangkan pada kadar zat menguap tidak ada yang memenuhi dimana standar SNI maksimal 15\%, untuk nilai kalor yang memnuhi stanbdar SNI $\geq 5000$ adalah dengan daya 440 watt.

\section{Bio Briket Cangkang Aleurites Moluccana Melalui Gelombang Elektromagnetik Dengan}


Tabel 1. Hasil Analisa Variasi Daya Microwave terhadap kualitas Bio Briket Cangkang Kemiri dalam waktu karbonisasi 1 jam

\begin{tabular}{clccccc}
\hline No & \multicolumn{1}{c}{ Analisa } & $\begin{array}{c}\text { SNI } \\
\text { Briket }\end{array}$ & $\mathbf{2 5 0}$ & $\mathbf{4 4 0}$ & $\mathbf{8 0 0}$ & $\mathbf{9 0 0}$ \\
\hline $\mathbf{1}$ & Kadar Air (\%) & $\leq 8$ & 7.39 & 7.30 & 7,09 & 6.44 \\
$\mathbf{2}$ & Kadar Abu (\%) & $\leq 8$ & 6.25 & 7.48 & 8,45 & 8.78 \\
$\mathbf{3}$ & Volatile mater (\%) & $\leq 15$ & 25.30 & 30,23 & 41.91 & 47.62 \\
$\mathbf{4}$ & Fix Karbon (\%) & $\geq 77$ & 72.21 & 73.31 & 69.95 & 67.24 \\
$\mathbf{5}$ & Nilai Kalor (kkal/gram) & $\geq 5000$ & 4521,14522 & 5706,24816 & 5124.59072 & 4643.16447 \\
\hline
\end{tabular}

Tabel 2. Hasil Analisa Variasi Daya Microwave terhadap kualitas Bio Briket Cangkang Kemiri dalam waktu karbonisasi 2 jam

\begin{tabular}{cllcccc}
\hline No & \multicolumn{1}{c}{ Analisa } & $\begin{array}{c}\text { SNI } \\
\text { Briket }\end{array}$ & $\mathbf{2 5 0}$ & $\mathbf{4 4 0}$ & $\mathbf{8 0 0}$ & $\mathbf{9 0 0}$ \\
\hline $\mathbf{1}$ & Kadar Air (\%) & $\leq 8$ & 7.54 & 6.63 & 6.43 & 6.21 \\
$\mathbf{2}$ & Kadar Abu (\%) & $\leq 8$ & 7.48 & 8.13 & 8.47 & 8,82 \\
$\mathbf{3}$ & Volatile mater (\%) & $\leq 15$ & 38.28 & 44.10 & 49.04 & 50.21 \\
$\mathbf{4}$ & Fix Karbon (\%) & $\geq 77$ & 71.05 & 64.90 & 65.86 & 64.21 \\
$\mathbf{5}$ & Nilai Kalor (kkal/gram) & $\geq 5000$ & 4421.35671 & 5174.70384 & 4786.15011 & 4521.65821 \\
\hline
\end{tabular}

\section{Pengaruh Daya Terhadap Kadar Air}

Nilai kadar air sangat berpengaruh terhadap kualitas bio briket yang dihasilkan. Dengan nilai kadar air yang kecil maka mengakibatkan nilai kalor dan daya pembakarannya akan semakin tinggi, begitupun sebaliknya.

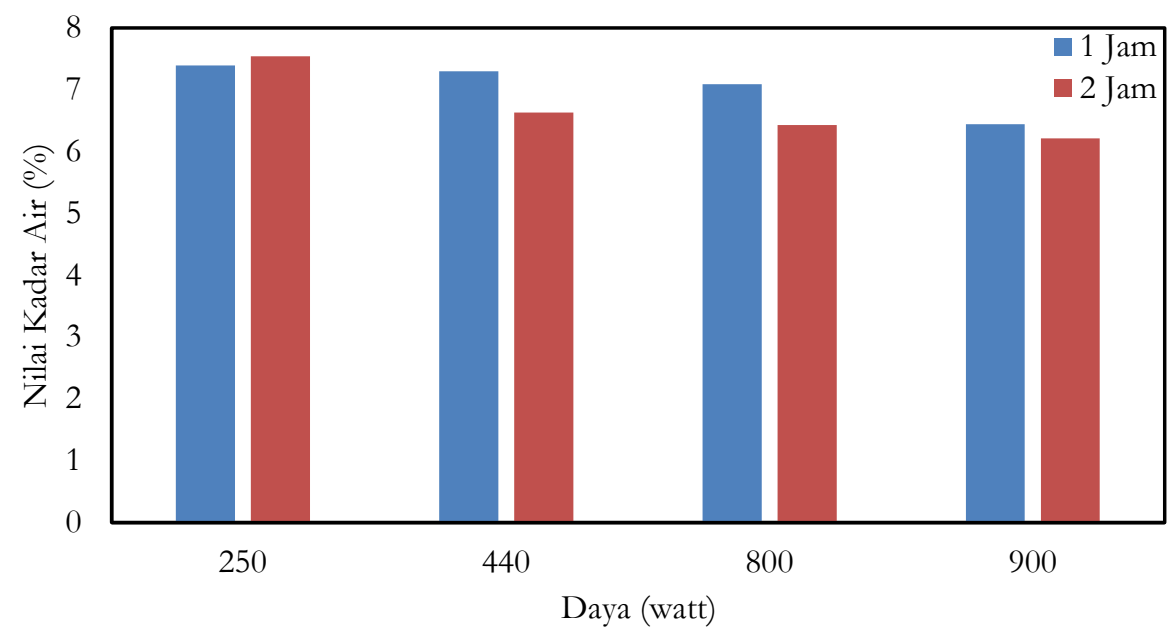

Gambar 3. Hubungan Kadar Air Bio Briket Cangkang Kemiri Dengan Daya Microwave

Gambar 3 menunjukkan variasi daya dan lama waktu karbonisasi akan mempengaruhi terhadap kadar air bio briket cangkang kemiri. Semakin tinggi daya, maka semakin tinggi suhu pemanasan yang diberikan pada arang cangkang kemiri, hal ini menjadikan air yang ada di dalam arang cangkang kemiri semakin sedikit atau dengan kata lain banyak air yang yang teruapkan. Dan dari hasil menunjukkan kandungan air yang dihasilkan memenuhi SNI yang berlaku dengan menggunakan bahan perekat dari tepung Ganyong. Dengan kecilnya kandungan air yang ada dalam bio briket cangkang kemiri akan menghambat terbentuknya jamur dan mudah dinyalakan.

Sedangkan penelitian terdahulu dalam penelitiannya menggunakan perekat dari Tepung sagu kandungan dengan menghasilkan kadar airnya 14,10\% sedangkan tepung tapioka kadar air yan g dihasilkan 
sebesar 9,84\%.10 Kadar air briket juga dapat menentukan sifat higroskopis dari briket tersebut. Briket yang memiliki kadar air tinggi akan sulit dinyalakan, mudah rapuh dan ditumbuhi jamur. ${ }^{3}$

\section{Pengaruh Daya Terhadap Kadar Abu}

Abu adalah merupakan bahan sisa dari proses pembakaran yang sudah tidak memiliki unsur karbon lagi. Kadar abu briket dapat dipengaruhi oleh kandungan abu dari bahan perekat atau bahan baku. Salah satu unsur utama penyusun abu adalah silika dan pengaruhnya kurang baik terhadap nilai kalor bio briket yang dihasilkan. Semakin tinggi kadar abu maka semakin rendah kualitas bio briket karena kandungan abu yang tinggi dapat mengakibatkan penurunan nilai kalor selain itu tingginya kadar abu dapat menghasilkan emisi debu yang menyebabkan polusi udara dan mempengaruhi volume pembakarannya.

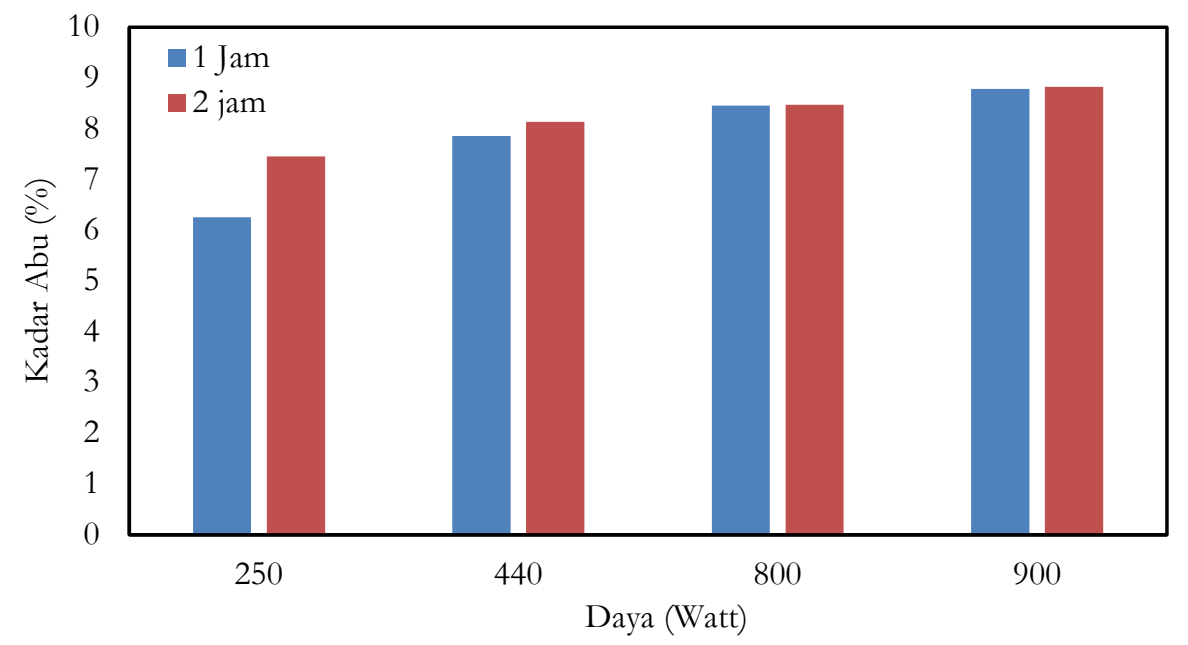

Gambar 4. Hubungan Kadar Abu Bio Briket Cangkang Kemiri Dengan Variasi Daya Microwave

Gambar 4 menunjukkan variasi daya dan lama waktu karbonisasi memberikan pengaruh yang berbeda terhadap kadar abu bio briket cangkang kemiri. Hal ini disebabkan karena adanya pengaruh dari kadar abu yang dimiliki oleh perekat. Semakin meningkat daya microwave semakin tinggi temperatur yang ada sehingga mengakibatlan peningkatan kadar abu yang dhasilkan. Dari hasil didapatkan kadar abu yang sesuai dengan SNI $\leq 8$ adalah pada daya microwave 250 dan daya 440 Watt. Hal ini disebabkan karena pada penelitian bahan perekat yang digunakan adalah tepung ganyong yang di analisa mempunyai kaandungan abu sebesar $3,05 \%$.

\section{Pengaruh Daya Terhadap Zat Mudah Menguap (Volatile Matter)}

Kadar zat menguap adalah zat yang menguap sebagai hasil dari penguraian atau dekomposisi senyawa yang masih terdapat di dalam arang selain air. Tinggi rendahnya kadar zat mudah menguap pada bio briket disebabkan oleh kesempurnaan proses karbonisasi, waktu dan suhu. Semakin lama waktu pembakaran dan semakin tinggi daya microwave pada proses karbonisasi maka semakin meningkat pula zat yang menguap keluar. Selain itu dapat juga dikatakan dengan semakin banyak zat volatil akan mengakibatkan semakin banyak asap yang dihasilkan, hal ini karena adanya reaksi karbon monoksida (CO).

Gambar 5 menunjukkan nilai zat menguap dengan adanya variasi daya microwave tidak memenuhi SNI karena nilainya di atas $15 \%$. Hal ini dikarenakan dengan daya microwave dan lama waktu karbonisasi yang tinggi mengakibatkan suhu di peralatan microwave semakin tinggi yang berdampak semakin banyak bahan yang teruapkan.

\section{Pengaruh Daya Terhadap Fix Karbon}

Karbon terikat (fixed carbon) adalah fraksi karbon (C) yang terikat di dalam arang selain fraksi air, zat menguap dan abu. Keberadaan karbon terikat di dalam briket arang dipengaruhi oleh kadar air, kadar abu dan kadar zat menguap. Kadarnya akan bernilai tinggi apabila kadar air, kadar abu dan kadar zat menguap pada briket rendah. Karbon terikat berpengaruh terhadap nilai kalor pembakaran bio briket. Nilai kalor briket arang akan tinggi jika nilai karbon terikatnya juga tinggi. 


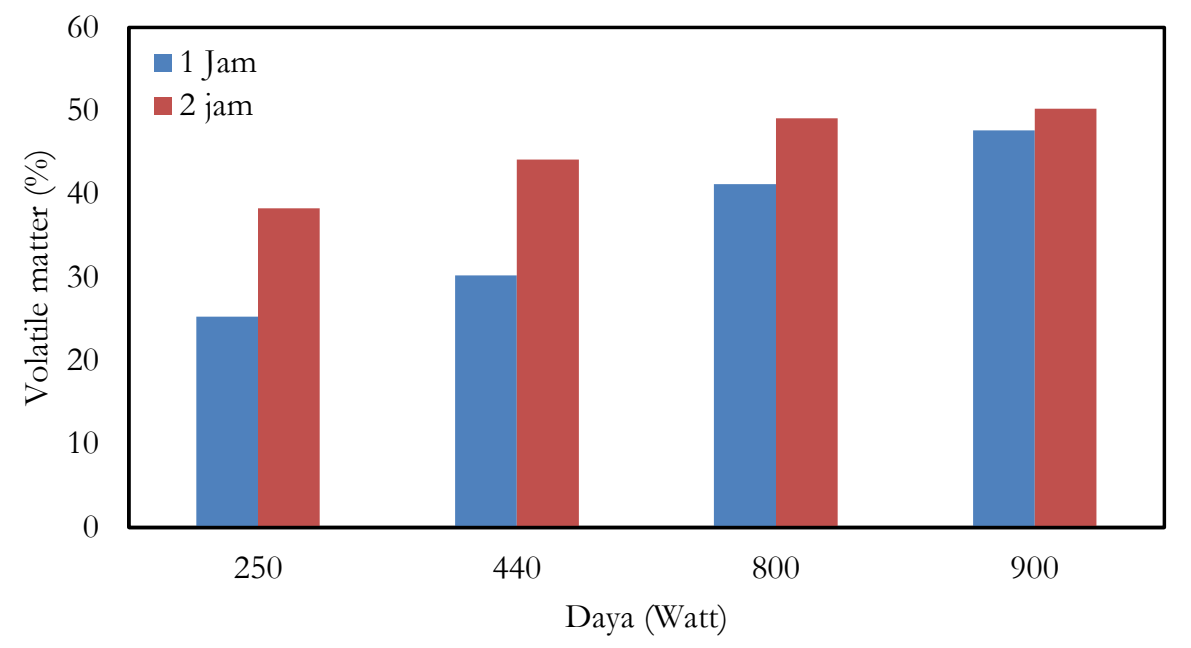

Gambar 5. Hubungan Volatile Matter (Zat Mudah Menguap) Bio Briket Cangkang Kemiri Dengan Variasi Daya Microwave

Gambar 6 menunjukkan variasi daya dan lama waktu karbonisasi memberikan pengaruh yang berbeda terhadap kadar karbon terikat bio briket arang cangkang kemiri yang dihasilkan. Semakin rendah nilai kadar air, kadar abu dan kadar zat menguap yang dihasilkan maka makin tinggi kadar karbon terikatnya. Dari hasil penelitian dengan variasi daya dan lama waktu karbonisasi tidak ada yang sesuai dengan SNI, hal ini dikarenakan semakin tinggi daya yang diberikan pada peralatan microwave maka menyebabkan perubahan terhadap nilai karbon padat yang berubah menjadi abu sehingga nilai karbonnya menurun. Nilai Karbon terikat yang paling tinggi didapatkan pada daya 440 watt dengan lama waktu karbonisasi selama 1 jam yaitu nilai karbon terikatnya adalah sebesar $73,31 \%$

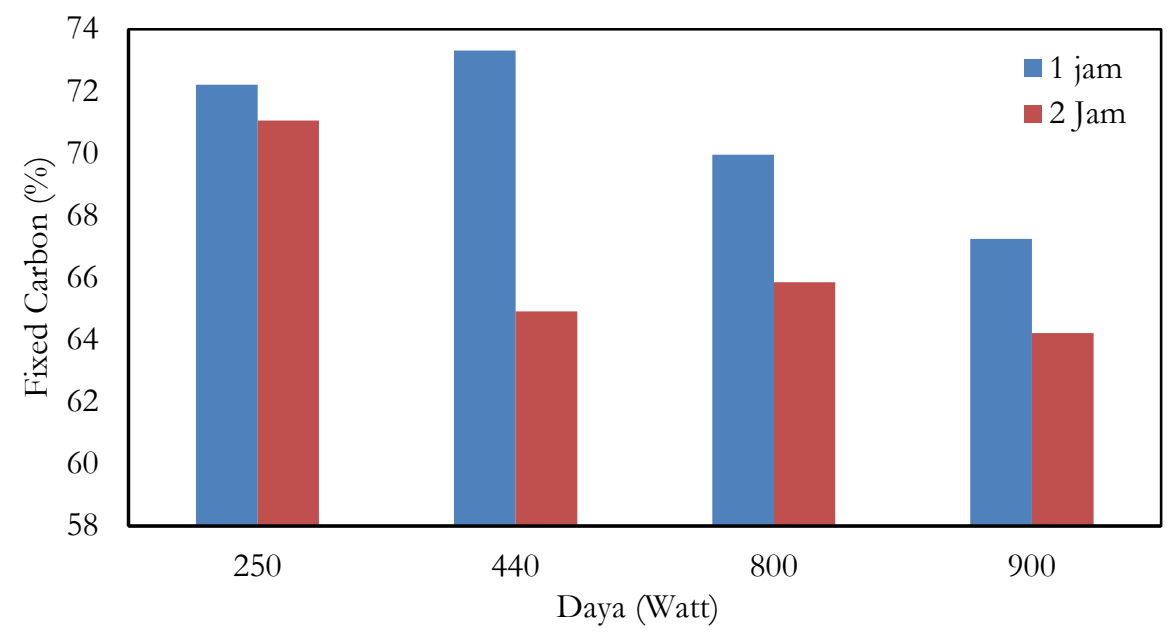

Gambar 6. Hubungan Karbon Terikat (Fixed Carbon) Bio Briket Cangkang Kemiri Dengan Variasi Daya Microwave

\section{Pengaruh Daya Terhadap Nilai Kalor}

Penetapan nilai kalor bakar bio briket merupakan salah satu parameter untuk menentukan kualitas briket dalam penggunaannya, layak atau tidak digunakan sebagai bahan bakar. Nilai kalor merupakan parameter utama pengukuran kualitas bahan bakar, bertujuan untuk mengetahui nilai panas pembakaran yang dihasilkan bio briket. Semakin tinggi kandungan karbon terikat pada briket arang maka semakin tinggi pula nilai kalor briket arang yang dihasilkan. Hal ini disebabkan karena di dalam proses pembakaran membutuhkan karbon yang akan bereaksi dengan oksigen untuk menghasilkan kalor. Dari Gambar 7 dapat dilihat bahwa variasi daya dan lama karbonisasi memberikan pengaruh terhadap nilai kalor bio briket. 


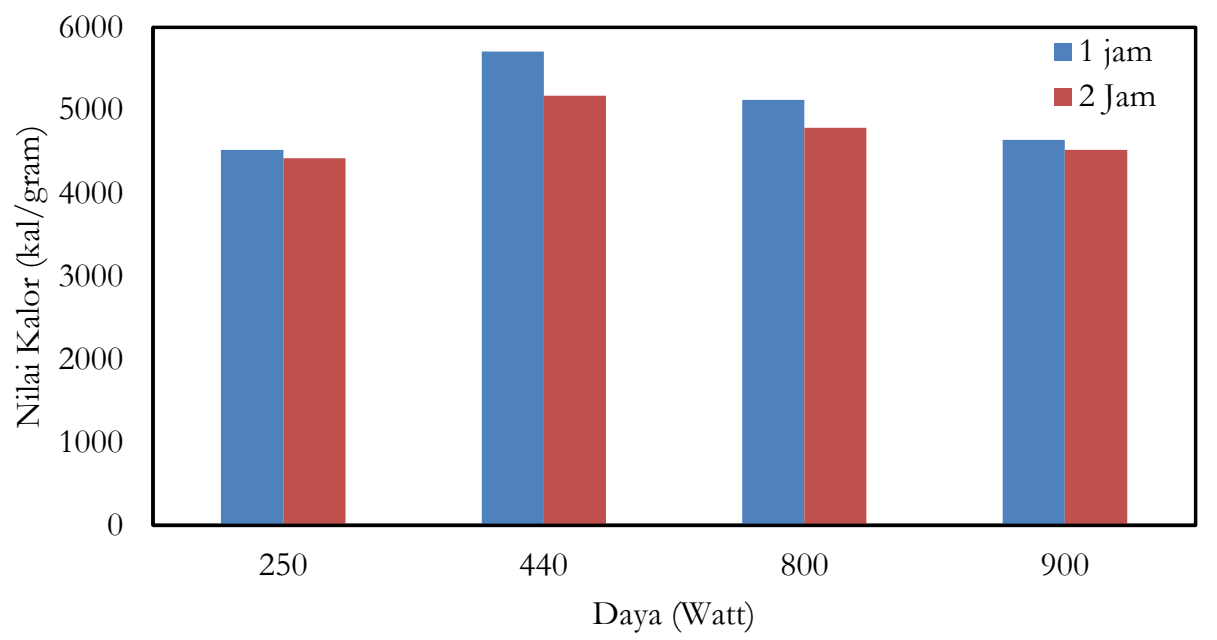

Gambar 7. Grafik Nilai Kalor Terhadap Kualitas Bio Briket Cangkang Kemiri Dengan Variasi Daya Microwave

Gambar 7 juga menunjukkan nilai kalor bio briket semakin menurun seiring dengan peningkatan daya dan lama waktu karbonisasi. Hal ini dikarenakan dengan bertambahnya daya maka banyak material yang ada di bio briket hilang karena suhu terlalu tinggi, mengakibatkan nilai kalor semakin menurun. Nilai kalor yang tertinggi dihasilkan dengan daya sebesar 440 Watt, yaitu nilai kalornya sebesar 5706,24816 kal/gram.

Dibandingkan dengan peneliti terdahulu didapatlan nilai kalor sebesar $6346 \mathrm{kal} / \mathrm{gr}$ dengan perekat tepung tapioka pada bio briket dari kayu karet. ${ }^{11}$ sedangkan peneliti lain menggunakan perekat yang sama yaitu tepung tapioka pada briket arang tempurung kemiri didapatkan nilai kalornya $5922.554 \mathrm{kl} / \mathrm{gram} .{ }^{12}$

\section{Kesimpulan}

Berdasarkan hasil dari variasi daya microwave dan lama waktu karbonisasi, maka didapatkan nilai optimum terdapat pada daya 440 Watt dan lama waktu karbonisasi selama 1 jam dengan karakteristik biobriket sebagi berikit nilai kadar airnya : $7.30 \%$, nilai kadar abu sebesar : 7.48 \%, Zat menguap (Voletile matter) : $30.23 \%$, Karbon terikat : $73.31 \%$ dan nilai kalor sebesar : $5706,24816 \mathrm{kal} / \mathrm{gram}$. Dari data tersebut dapat disimpulkan bahwa biobriket cangkang kemiri dapat diaplikasikan baik skala kecil atapun menengah dikarenakan hampir semua analisa yang ada sesuai dengan Standar Nasional Indonesia.

\section{Referensi}

[1] Pari, G.. Pengarub Lama Aktivasi Terbadap Struktur Kimia Dan Mutu Arang Aktif Serbuk Gergaji Sengon, Jurnal Penelitian Hasil Hutan. Pusat Penelitian dan Pengembangan Hasil Hutan. Bogor, 2005, 23(3):207218

[2] Sudrajat, R., Pembuatan Arang Aktif Dari Tempurung Biji Jarak Pagar, Jurnal Penelitian Hasil Hutan, Pusat Penelitian Dan Pengembangan Hasil Hutan. Bogor. 2005, 23(2);143-162

[3] Maryono, Sudding \& Rahmawati, Pembuatan dan Analisis Mutu Briket Arang Tempurung Kelapa Ditinjau dari Kadar Kanji, Jurnal Chemical, 14(1), 2013, 74-83.

[4] Lestari, L., Aripin, Yanti, Zainudin, Sukmawati, Marliani, Analisis Kualitas Briket Arang Tongkol Jagung yang Menggunakan Bahan Perekat Sagu dan Kanji, Jurnal Aplikasi Fisika, vol. 6 no.2, 2010.

[5] B, G.A., Pengaruh Variasi Jumlah Perekat Terhadap Karakteristik Briket Arang Tongkol Jagung, PROFESIONAL, Vol. 8. No. 1. Mei 2010, 2010,ISSN 1693-3745.

[6] Sarjono, Studi Eksperimental Perbandingan Nilai Kalor Briket Campuran Bioarang Sekam Padi dan Tempurung Kelapa, Makalah Ilmiah STTR Cepu., 2013. ISSN 1693-

[7] Hanandito, L., Willy, S., Pembuatan Briket Arang Tempurung Kelapa Dari Sisa Bahan Bakar Pengasapan Ikan Kelurahan Bandarbarjo Semarang, (2011)

[8] Suryani, I., Permana, M. Y., Dahlan, M. H, Pembuatan Briket Arang Dari Campuran Buah Bintaro dan Tempurung Kelapa Menggunakan Perekat Amilum, Universitas Sriwijaya Palembang, 2012

Bio Briket Cangkang Aleurites Moluccana Melalui Gelombang Elektromagnetik Dengan 
[9] Rini Kartika Dewi, M. Istnaeny Hudha, Anindita, Safarina T., Karakteristik Proses Delignifikasi Limbah Cangkang Kemiri Menggunakan Microwave dan larutan $\mathrm{NaOH}$, Prosiding Seminar Nasional Teknik Kimia Eco-Smart 2019,35 - 42

[10] Ndraha, N.. Uji Komposisi Bahan Pembuat Briket Bioarang Tempurung Kelapa dan Serbuk Kayu terhadap Mutu yang Dihasilkan. Medan: Universitas Sumatera Utara. (2009)

[11] Muhammd Faizal, Ismira Andynapratiwi, Puput Destriana Ayu Putri, Pengaruh Komposisi Arang dan perekat Terhadap Kualitas Biobriket Dari kayu Karet, Teknik Kimia, No. 2, Vol. 20, 2014

[12] Ika Yudita Permatasari, Budi Utami, Pembuatan dan karakteristik Briket Arang Dari Limbah Tempurung Kemiri (Aleurites Moluccana) Dengan menggunakan jenis Bahan Perekat dan Jumlah Bahan Perekat, Prosiding Seminar Nasional Kimia 2015, Jurdik Kimia-Fmipa-UNY, ISBN 978-60214548-2-4, 2015, hal. 59-69 